XII. On Ornix Meleagripennella and its Allies; a Group of Lepidoptera, Family Tineidæ. By H. T. Stainton, Esq.

TiLl the appearance of the second volume of the Linnæa Entomologica, in which Herr Zeller described Ornix anguliferella, I believe there was no suspicion that with Meleagripennella were confounded several very closely allied species. Haworth, it is true, had in his "Lepidoptera Britannica," described at p. 532 Gracillaria nebulea-" alis anticis cinereis, nebulis magnis nigris, costa fasciis nigris, strigis albidis interrupta," which is manifestly one of this group; and at p. 578 he has Tinea meleagripennella"alis cinereis apice punctulo ocellari atro," which he places after Cramerella, observing "pracedente minor et angustior;" but it appears to have been known to him from only a single specimen, and as little information is to be gained from his description, and he does not attempt to compare it with his Nebulea, we may safely consider that Haworth was acquainted with this group only under the name of Nebulea. Mr. Stephens has certainly two descriptions in his Illustrations, vol. iv. p. 364, applicable to this group; viz. Nebulea and Meleagripennella; but these species are not compared with each other, and there is nothing to identify them with any species with certainty. His Nebulea may have been either the Meleagripennella or the Anglicella of this paper, and his Meleagripennella may have been either the Anglicella or the Torquillella of this paper. Hübner's figure of Meleagripennella No. 189, is much too coarse to be identified with any species. Treitschke's description of Meleagripennella, vol. ix. 2, p. 209, and Duponchel's, supp. vol. iv. p. 467 , pl. 86, f. 4 , are both unsatisfactory and are not sufficiently precise to be identified with any of the species I am about to enumerate. I have now brought the history of the literature of this group up to the appearance in 1847 of Zeller's Monograph, in the second volume of the Linnæa Entomologica, where we are first informed that there is a species very closely allied to Meleagripennella. The mere statement of this fact, having had the effect of causing Entomologists to examine their specimens in order to try and detect Anguliferella lurking in their collections, has resulted in the discovery of at least six additional species. In my monograph of Argyromiges, in the Zoologist, I described at p. 2162 one of this group, under the 
name of Loganella. The specimen from which this description was made being destitute of cilia, I was at that time not at all aware of its relationship, but in my Catalogue it appears in its proper place, p. 23, after Meleagripennella. In the May number of the Entomologische Zeitung, of the present year, Zeller describes two new species of this group, p. 161, under the names of Torquillella and Finitimella. Ampliatella, the very beautiful new species discovered last year by Herr Mann, at Fiume, will probably be described in the Publications of the Imperial Academy of Vienna; but the knowledge that it is there described will be small consolation to Entomologists, to whom such a work is almost unattainable. It is a great pity but that Herr Mann had sent his descriptions of new species to the Stettin Society, to ap. pear in its widely-circulated Zeitung.

I briefly recapitulate the generic characters, as given by Zeller in the Linnæa.

\section{Ornix (Tr.), Z.}

Caput lanatum. Palpi labiales squamis appressis, fasciculo pilorum nullo.

Readily distinguished from the genera, Gracilaria and Coriscium, by the woolly head, by the labial palpi being destitute of a tuft of hairs, and by the broader anterior wings.

In their general appearance and mode of sitting, the insects are at once recognised as allied to Gracilaria.

Treitschke's observations on the larva and pupa (which were communicated to him by Fischer-von-Röslerstamm) appear to me most appropriately appended-here, since we are at present unable to attach them to any one species, though future observations may enable us to do so. "The fourteen-footed larva feeds in September in the united leaves, or the turned-down edges of leaves, and certainly always on the underside, of mountain ash, blackthorn, and birch. It is yellow-green, almost transparent, with hardly perceptible little warts of the same colour. The head likewise, with brown spots on the sides. The similarly coloured thorax has two stronger, and two fainter brown spots. The claws are brown, spotted.

"At the end of September or in October it shuts itself up in its habitation, for which purpose it weaves therein a narrower and firm brownish case. Before winter it changes into a thin, very long pupa, which is at first yellow, and afterwards becomes greybrown, and has long leg and tongue sheaths reaching beyond the anus." 
The following is my arrangement of the species :-

A. With the palpi spotted.

A. The last joint of the palpi with a dark spot underneath.

1. Meleagripennella. Anterior wings pale grey; no white line

2. Devoniella. along the hinder margin.

3. Anguliferella. Anterior wings grey, with a white line along the hinder margin.

5. Loganella. Anterior wings black.

B. The last joint of the palpi encompassed with a broad blackbrown ring interrupted on the upper side.

4. Finitimella.

c. The last joint of the palpi encompassed by a broad uninter-

6. Anglicella. rupted black-brown ring.

B. With the palpi entirely white.

7. Torquillella.

A. Face grey.

B. Face white.

8. Scoticella. Anterior wings grey, with the base and inner margin whitish.

9. Ampliatella. The ground colour of the basal half of the anterior wings white.

Of these nine species, three have not yet been discovered in Britain; viz. Anguliferella, Finitimella and Ampliatella; two, Meleagripennella and Torquillella, are common to this country and the continent; and four, Devoniella, Loganella, Anglicella and Scoticella, are exclusively British, not having yet been discovered on the continent.

Sp. 1. Meleagripennella, Zeller.

Alis anticis pallidè fusco-cinereis, dorso albido farinato, costæ strigulis numerosis albidis, ciliis externe fusco-cinctis, puncto atro apicali nullo.

Meleagripennella, Z. (Linnæa Entomologica, vol. ii. p. 374.)

Distinguished from its allies by the pale grey anterior wings having no strongly marked black spot at the apex.

Head and thorax whitish grey, with some brown hairs inter- 
mixed; face white; antennæ white, annulated with brownish; palpi white, with a greyish spot on the under side of the terminal joint; the four anterior legs brownish, spotted with white, tarsi white, with brown ends to the joints; hind legs dirty yellowishgrey, tarsi brownish, with the basis of the joints whitish.

Anterior wings five times as long as broad, pale grey, intermixed with white, especially along the inner margin; along the costa are numerous oblique white streaks, those nearest the apex gradually become longer and less oblique, the five last are much more distinct than those which precede; in the fold of the wing, beyond the middle, is a darker brown spot, and another near the anal angle; at the apex of the wing is a dark ocellus-like spot (not nearly so dark as in the following species); cilia whitish, with a curved dark line from the apex to the inner margin, followed by a second line beyond it, but only corresponding to the lower half of the first line.

Posterior wings six times as long as broad, gradually pointed, grey, with paler cilia.

This species will, probably, eventually prove common; but at present it is a scarce species with us. I have once or twice taken it at Lewisham, but more frequently at West Wickham Wood. It is not improbable that it is a birch feeder. It is, probably, often overlooked as a pale specimen of our commonest species Anglicella. It occurs in many parts of the Continent; but whether all the localities given by Zeller for this species really belong to it, individually, is very questionable.

\section{Sp. 2. Devoniella, n. sp.}

Alis anticis ochraceis, dorso albido farinata, costæ strigulis numerosis indistinctis albidis, ciliis-externe ochraceo-cinctis, puncto apicale atro.

Readily distinguished from any of its known congeners by its ochre-coloured anterior wings. A further point of distinction between it and the preceding species is the deep black apical spot.

Head and thorax whitish, with some ochreous hairs intermixed; face white; antennæ white, annulated with pale grey; palpi white, with a faint appearance of a dark spot on the under side of the terminal joint; the four anterior legs ochreous, spotted with whitish, tarsi whitish, the ends of the joints ochreous; hind legs dirty ochreous, tarsi dirty ochreous, with the bases of the joints whitish. 
Anterior wings five times as long as broad, ochreous, intermixed with white, especially along the inner magin; along the costa are numerous indistinct, short white streaks, towards the apex they become longer and more distinct; in the fold of the wing, beyond the middle, is a spot of darker ochre; at the apex is a distinct deep-brown or black ocellated spot; cilia whitish, with a curved ochreous line from the apex to the inner margin.*

Posterior wings six times as long as broad, pale grey, with ochreous cilia.

Of this beautifully distinct species I took a single specimen on the 1st of May, 1850, in a lane near Dawlish, in Devonshire. I beat it out of a hedge in which there was a great deal of birch, but also bramble, sallow, hornbeam and honeysuckle. I beat the same hedge most assiduously the whole of the next day, but without having the good fortune to meet with another specimen.

\section{Sp. 3. Anguliferella, Zeller.}

Alis anticis cinereis, dorso albido farinato, costæ strigulis numerosis albidis, linea albida ab angulo anale ad apicem, ciliis externe bis fusco-cinctis.

Anguliferella, Zeller. (Linnæa Entomologica, vol. ii. p. 377;

(Z. Ent. Zeitung, 1850, p. 162.)

Best distinguished from all the allied species, by the whitish line which runs along the hinder margin, from the anal angle to near the apex.

Head and thorax whitish-grey, with some darker hairs intermixed; face white; antennæ white, annulated with brownishgrey; palpi white, with a blackish spot on the under side of the terminal joint; the four anterior legs grey, spotted with white, the tarsi white, with the end of the joints dark brownish-grey; hind legs whitish, spotted with grey, tarsi brownish-grey, with the bases of the joints whitish.

Anterior wings four times as long as broad, pale grey, intermixed with white, especially along the inner margin; along the costa are numerous short white streaks, the five last being much the most distinct, and longer than the others; the fifth from the

* I believe this should be followed by a second outer line, at the lower half of the cilia, as in the preceding species; but my specimen is a little rubbed at the extreme tips of the cilia. 
apex is produced towards the apex of the wing, and there meets the hinder marginal white line, forming with it an acute angle (hence the name); on the fold of the wing are two dark spots, one before the middle, the other a little beyond; at the apex of the wing is a dark ocellus-like spot; cilia whitish, with two complete curved dark lines from the apex to the inner margin.

Posterior wings five times as broad as long, blunter than in the two preceding species, grey, with paler cilia.

Of this species I lave not yet seen a British specimen; the specimen I have described was sent me by Herr Zeller, who states in the Zeitung that the species occurs " in a small garden at Breslau, not scarce on orchard trees."

\section{Sp. 4. Finitimella, Zeller.}

"Minor, alis anticis fusco-cinereis, glaucescentibus, costa albido-strigulata, ciliis apicis obtusis externe fuscocinctis, epistomio fuscescenti, palpis albidis, annulo articuli ultimi lato fusco." Ent. Ztg. 1850, p. 162.

"Even smaller than Meleagripennella; its anterior wings are darker, with the violet gloss of Torquillella, and with smaller, fainter costal streaks; the cilia of the apex of the wing have the complete brown double encompassing-line as in Torquillella; face brownish-grey ; the whitish palpi have the terminal joint encompassed at the base with a broad black-brown ring, interrupted on the upper side." Z. l. c.

I have never yet seen a British specimen of this insect, and having only a bad foreign specimen, unfit for description, I have been obliged to copy Zeller's description in the Entomologische Zeitung, in order to make this memoir as complete as possible. Zeller says it occurs " at Glogau (a fine male on the 25th July) and at Jena."

\section{Sp. 5. Loganella, Stainton.}

Alis anticis atris, dorso maculis duabus albis, costa albostrigulata, ciliis fuscis.

Loganella, Stainton, Zoologist, 1848, p. 2162.*

Not likely to be confounded with any of its congeners.

* The figure there shown, Pl. 3, f. 37, is very bad, and hardly gives an idea of the insect. 
Head greyish, with some brown hairs intermixed; face brownish; antennæ dark grey, with paler annulations; palpi white, with a faint appearance of a dark spot on the under side of the terminal joint; thorax black, with a few whitish scales; legs dark grey; the four anterior tarsi white, with the ends of the joints dark grey; the posterior tarsi dirty ochreous.

Anterior wings five times as long as broad, very dark grey or black, not irrorated with whitish, as in the allied species, the white marks are few in number, and from the contrast of colour, stand out very prominently; on the inner margin, towards the base, are a few white scales; about the middle of the inner margin is an oblong white spot, and a little beyond the middle of the inner margin is another smaller white spot, followed by a few white scales at the anal angle; along the costa are several short white streaks, of which the four nearest the apex are the most distinct, the fourth from the apex is connected by white scales with the second inner-marginal spot, thus forming, as it were, a white fascia; the apical streak is continued round the black ocellated spot to the hinder margin; cilia at the apex whitish, surrounded by a black curved line; cilia at the anal angle dark grey.

Posterior wings five times as long as broad, grey with paler cilia.

This species was discovered by Mr. R. F. Logan (after whom I have named it); he took a single specimen off a hazel bush near Luss, in Dumbartonshire, on the evening of the 5th of July, 1847; this remained unique till this year, when a second specimen was taken by Mr. Jobson, at Kilmun, about the middle of June.

This species appears to form a connecting link between this group and Guttea.

$$
\text { Sp. 6. Anglicella, n. sp. }
$$

Alis anticis cinereis, dorso albido farinato, costa albido-strigulata, ciliis externe bis fusco-cinctis; palpis albis, articulo tertio annulo lato fusco.

Nebulea, Haw.?

Meleagripennella, St.?

Distinguished from Meleagripennella by the much darker anterior wings, and from Torquillella and Scoticella by the broad black ring on the terminal joint of the palpi. 
Head whitish grey, with some ochreous, and dark grey hairs on the crown of the head; face grey; antennæ whitish, annulated with dark grey; palpi white, the terminal joint with a broad dark grey or black ring, leaving only its base and apex white; thorax whitish-grey, with some dark grey scales; the four anterior legs dark grey, spotted with whitish, tarsi white, with the ends of the joints dark grey; hind legs dirty brownish ochre, tarsi rather darker, with the bases of the joints paler.

Anterior wings five times as long as broad, dark grey intermixed with white, especially along the inner margin; along the costa are numerous short white streaks, those towards the apex being most distinctly marked, and the apical one is continued round the ocellated apical black spot, to the hinder margin; in the fold of the wing are two distinct oblong black spots, one before, the other beyond the middle, and between this latter and the apex of the wing is a smaller black spot, bounded externally by a whitish mark, which appears to form a continuation of the costal streak situated the fifth from the apex; cilia whitish, with a complete curved black line from the apex to the inner margin, followed by a second almost as complete, but slightly interrupted at the extreme apex.

Posterior wings six times as long as broad, pale grey, with paler cilia.

By far the commonest species of the group in the south of England; at Lewisham it swarms in every hedge in May, and again in July. I have sent specimens of it to Herr Zeller, who pronounces it quite new to him.

Sp. 7. Torquillella, Zeller.

Alis anticis cinereis, glaucescentibus, dorso albido farinato, costa albido-strigulata, ciliis externe fusco-cinctis; palpis albis, immaculatis; epistomio cinereo.

Torquillella, Zeller, Entomologische Zeitung, 1850, p. 161.

Distinguished from all the preceding species by the white palpi being entirely unspotted, and from Scoticella by the darker face, darker base of the anterior wings, and less sharply defined markings on the anterior wings.

Head ochreous grey, with some darker hairs intermixed; face grey ; antennæ dark grey, with paler annulations; palpi entirely white; thorax whitish grey, with some darker scales; the four 
anterior legs dark grey, spotted with whitish, tarsi white, with the ends of the joints dark grey; hind legs dirty brownish, tarsi pale, with the ends of the joints darker.

Anterior wings five times as long as broad, dark grey with a purple gloss, with the inner margin whitish, and with several short whitish streaks along the costa, the fifth before the apex being continued obliquely across the wing towards the anal angle, and the apical streak continued round the ocellated black spot, to the hinder margin; in the fold of the wing are two oblong black spots, one before, the other beyond, the middle, and between this latter and the continuation of the costal streak, which is fifth from the apex, is a smaller black spot; cilia whitish, with two complete curved dark lines from the apex to the inner margin.

Posterior wings six times as long as broad; pale grey, with paler cilia.

This species appears rather partial to the chalk here. I have taken it at Sanderstead in May, and at Mickleham in July. It has been taken in Italy by Herr Mann, near Florence, Pisa and Leghorn, " everywhere abundant on blackthorn." Zeller states that it also " occurs near Vienna and Jena."

\section{Sp. 8. Scoticella, n. sp.}

Alis anticis nigro-cinereis, basi dorsoque albido farinato, costa albo-strigulata, ciliis apicis externe bis fusco-cinctis, palpis albis immaculatis; epistomio albido.

Resembles Torquillella in having unspotted white palpi, but readily distinguished from that species by the paler face, paler base, and whiter markings of the anterior wings.

Head white, with a few grey hairs on the crown; face white ; antennæ dark grey, with paler annulations; palpi white, unspotted; thorax white, intermixed with grey; the four anterior legs dark grey, spotted with white, tarsi white, with the ends of the joints dark grey; hind legs dirty brownish grey, tarsi the same, with the bases of the joints paler.

Anterior wings five times as long as broad, dark grey, with the base and inner margin copiously sprinkled with whitish; along the costa are numerous short white streaks, the fifth before the apex being continued towards the anal angle, and the apical one being continued round the apical black spot to the hinder margin; in the fold of the wing are two deep black oblong spots, one before and the other beyond the middle (the third spot is lost in the dark 
ground colour of the apical portion of the wing); cilia greyish, with two complete curved dark lines from the apex to the inner margin.

Posterior wings six times as long as broad, rather pointed, grey, with paler cilia.

I had the good fortune to discover this species in Torwood, in June, 1849, in considerable plenty; the insects, when alive, have a greenish appearance (which they entirely lose after death); I was thus struck with them at the time, but only suspected it to be a northern variety. In September, 1849, I collected a number of small larvæ in this locality, and in June of this year I had the pleasure of breeding a specimen of the insect from one of these larvæ found on mountain ash. I have never met with it in any other locality, and the species has not yet been detected on the continent.

\section{Sp. 9. Ampliatella, Mann.}

Alis anticis albidis, cinereo-irroratis, apicem versus suffusis, costa nigro-strigulata, maculis nigris tribus in disco; ciliis apicis externe bis fusco-cinctis; palpis albis immaculatis; epistomio albo.

Ampliatella, Mann in litt.

Known at once from all its congeners by the general whiteness of the anterior wings.

Head white, with a few grey hairs ; face white ; antennæ grey, with paler annulations; palpi white, unspotted; thorax white, intermixed with grey; the four anterior legs dark grey, spotted with white, the tarsi white, with the ends of the joints blackish; hind legs dirty greyish white, tarsi the same, with the ends of the joints darker.

Anterior wings four times as long as broad, white, irrorated with grey; along the costa are numerous short black streaks, which, by their union, form a dark grey patch at the apex of the wing, where accordingly the ground colour seems reversed, the markings at the apex appearing white on a dark ground, whereas in the remaining portion of the wing the markings appear dark on a white ground; the apical white costal streak is continued round the ocellated black spot to the hinder margin; in the fold of the wing are two conspicuous oblong black spots, one before and the other beyond the middle; the third spot occupies its usual place, but is not as conspicuous as the other two; cilia whitish, with two 
complete curved dark lines from the apex of the wing to the inner margin. cilia.

Posterior wings five times as long as broad, grey, with paler

This very beautiful species was discovered last year in Croatia by Herr Mann, of Vienna; of its food and time of appearance I know nothing. It appears to form a connecting link between this group and Caudulatella.

I have not thought proper to extend this paper to a Monograph of the entire genus Ornix, the species allied to Meleagripennella form such a very distinct group, and at present we only know of one other British species in the genus, Guttea. On the continent two other species are known; one Calatella, Zeller (Linn. Ent. vol. ii. p. 585), somewhat allied to Guttea, with silvery white markings along the costa; the other, Caudulatella, somewhat resembling Ampliatella, but with a black hook in the apical cilia. It is by no means improbable that Guttea and Caudulatella may both form centres of groups of species, as is the case with $M e$ leagripennella, and I would therefore advise collectors to keep a sharp eye to any aberrant specimens of these species, besides bearing in mind, that the allies of Meleagripennella $\mathrm{I}$ have here enumerated are probably not the whole number of these species, and that many allied species may yet have to be discovered. 


\section{$2 \mathrm{BHL}$ Biodiversity Heritage Library}

Stainton, H. T. 1850. "XII. On Ornix Meleagripennella and its Allies; a Group of Lepidoptera, Family Tineidæ." Transactions of the Entomological Society of London 6, 86-96. https://doi.org/10.1111/j.1365-2311.1850.tb02487.x.

View This Item Online: https://www.biodiversitylibrary.org/item/55127

DOI: https://doi.org/10.1111/j.1365-2311.1850.tb02487.x

Permalink: https://www.biodiversitylibrary.org/partpdf/56846

\section{Holding Institution}

Smithsonian Libraries

\section{Sponsored by}

Smithsonian

\section{Copyright \& Reuse}

Copyright Status: Public domain. The BHL considers that this work is no longer under copyright protection.

This document was created from content at the Biodiversity Heritage Library, the world's largest open access digital library for biodiversity literature and archives. Visit BHL at https://www.biodiversitylibrary.org. 